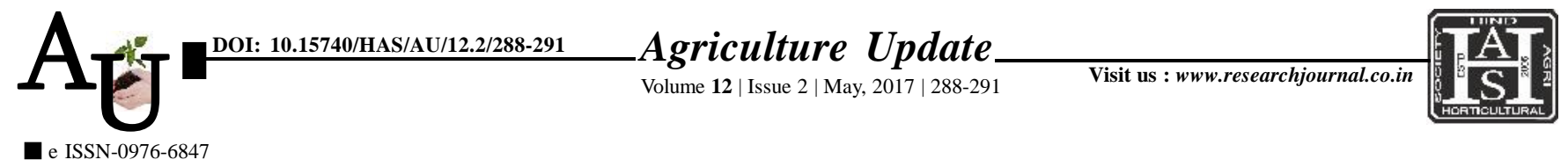

\title{
Research Article: Impact of intensive watershed development project
}

\author{
V.S.TEKALE, MOSAMI INGALE AND VIDYA V. TAYDE
}

Article Chronicle:

Received :

29.01.2017;

Revised :

05.04.2017;

Accepted :

21.04.2017

\section{KeY Words:}

Watershed

development project, Respondents, VIWDP
SUMMARY : The study of impact of Vidarbha intensive watershed development project on its beneficiary farmers was conducted in Yavatmal district of Vidarbha region of Maharashtra state. The sample consisted of 100 beneficiary farmers from 3 different villages of Arni, Digras and Darwha talukas of Yavatmal district were randomly selected. Data were collected on personal, socio-economic, communicational and psychological characteristics related to agriculture with the help of pre structured and pretested interview schedule. The result showed that, in case of characteristics of respondents farmers, majority of respondents $(52.00 \%)$ belonged to middle age group, nearly half of the respondents $(42.00 \%)$ were educated upto secondary school, family size of respondents was in medium $(46.00 \%)$. Majority of the respondents (51.00\%) had medium land holding and moderately deep soil type (52.00\%). High proportion of respondents $(42.00 \%)$ had high annual income. Over half of respondents $(57.00 \%)$ belonged to medium social participation. Majority of the respondents $(74.00 \%)$ had medium mass media exposure and medium innovativeness $(55.00 \%)$. The majority of the respondents $(63.00 \%)$ had high source of irrigation and major source of irrigation of 76 per cent respondents was canal irrigation. The impact of VIWDP on beneficiaries farmers showed that in case of change in cropping pattern over half of the respondents $(57.00 \%)$ had medium change in cropping pattern and 31.00 per cent had high change. Majority of respondents (57.00\%) had medium change in their cropping intensity and 27.00 per cent high change. Over half of the respondents $(66.00 \%)$ had medium change in crop production. Nearly three fourth of the respondents $(73.00 \%)$ had medium change in crop productivity and 19.00 per cent respondents observed high change in productivity. In case of income due to VIWDP 65 per cent respondents change income at medium level and 20 per cent respondents at high level. Majority of the respondents (59.00\%) said that no change in their agriculture occupation. The overall impact of VIWDP on beneficiary farmers was 78.82 per cent. In case of relational analysis of characteristics of respondents with overall impact of VIWDP, it was observed that education, land holding, soil type, annual income, social participation, mass media exposure, innovativeness and source of irrigation was positively and highly significantly correlated with impact of VIWDP. Whereas, age and family size were non-significantly correlated with overall impact of VIWDP.

How to cite this article : Tekale, V.S., Ingale, Mosami and Tayde, Vidya V. (2017). Impact of intensive watershed development project. Agric. Update, 12(2): 288-291; DOI : 10.15740/HAS/AU/12.2/288-291.
Author for correspondence :

\section{VIDYA V. TAYDE}

Extension Education

Section, College of

Agriculture, NAGPUR

(M.S.) INDIA

See end of the article for

authors' affiliations 